\title{
A Study on Paradigm Shift for Retail Credit Growthin Bank of India Bangalore Zone
}

\author{
Prof. Rekha DM1', Niharika. $S^{2}$ \\ ${ }^{1}$ Assistant Professor, ${ }^{2}$ Student M.com \\ 1,2Department of Post Graduate Studies [M.Com], SJR College for Women, Bangalore, Karnataka, India
}

\begin{abstract}
How to cite this paper: Prof. Rekha DM | Niharika. S "A Study on Paradigm Shift for Retail Credit Growthin Bank of India Bangalore Zone" Published in International Journal of Trend in Scientific Research and Development (ijtsrd), ISSN: 24566470, Volume-3 | Issue-4, June 2019, pp.510-513, URL: https://www.ijtsrd.c om/papers/ijtsrd23 781.pdf

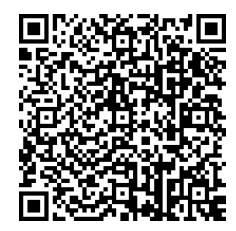

IITSRD23781
\end{abstract}

Copyright (C) 2019 by author(s) and International Journal of Trend in Scientific Research and Development Journal. This is an Open Access article distributed under the terms of the Creative Commons

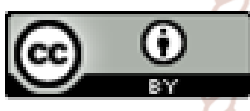
Attribution License (CC BY 4.0) (http://creativecommons.org/licenses/ by/4.0)

\section{INTRODUCTION}

Basic supply retailing flourishes, and has been intertwined into the Indian social texture since days of yore. It served the poor shoppers through various courses and stages, for example, neigh borhood mother and pop stores, town market sand the like. It encouraged the trading of products and enterprises for cash and to a great extent stayed sloppy and unregulated. India has been a country of shopkeepersaround 14 million retailers more retail shops than the remainder of the world set up together (Juyal S.A., 2012). Anyway the retailing in new thousand years remains as an energizing background to the shopper on the one side and proclaiming new vistas of chances and forcing immense difficulties to the retailers on the other side. Retailing in India has been developing at a frantic pace over the previous decade. All the more critically it has seen fast changes as far as the retail blend the quality and size of retail-ing, the assortments of retail organizes and furthermore changes in shopper inclinations and shopping propensities (Richa,2011). Concerns were raised that the development of modern retailing may adversy affect little retailers.

\section{Review of Literature}

$>$ Available literature provides contrasting perspectives; it supports in some ways and contradicts in many ways the view that modern and traditional grocers can harmoniously coexist and supplement each other in meeting the rising consumer demand for quality grocery and food items at competitive prices(Kalhan, 2007; Vijayakumar, 2008; Mathew, et al 2008; Shaik, 2009).

Fernandes et al (2000) opined that liberalization in India had opened up the country's markets to larger retailers and foreigcompanies, thus increasing the number of choices available to Indian consumers. The companies are increasingly building their supply chains in India and working to understand the Indian market.

$>$ Bat and Cadilhon (2007) reported that thretailing of grocery and fresh produce in modern for-mat is rapidly evolving in many developing countries such as Kenya Brazil China and the like and making inroads into India.

$>$ Vijay (2007) observed that the retail institutions play a crucial role in attracting and satisfying target customers. The diversity and changing nature of society has compelled retailers to change their store formats to provide a complete shopping experience to customers. Kalhan (2007) found a decline in sales of groceries fruits and vegetables processed foods gar-ments shoes electronic and electrical goods in the small retail outlets where large retail stores have come up in Mumbai. Vijay Kumar et al (2008) outline the concerns about the entry of modern retailers in the Indian food sector however it was concluded that though the-concern are valid there are more winners than losers in the process. 
$>$ Mathew Joseph et al (2008) found that unorganise retailers in the locality of organised retailers faced a decline in sales and profit in the initial years; the adverse impact however weakens over the time. Shankar \& Priya (2009) contend that corporate food provision will accelerate many key elements of India's agricultural crisis rather than being a pana- cea for Indian agriculture.

$>$ Shaik (2009) contends that the modernization of the Indian retail sector is being reflected in growth in sales of supermarkets depart- ment stores and hypermarkets. The author shares the concerns that existence of local grocery shops, owner- manned general stores, pan/beedi shops, convenience stores and handcart pavement vendors, small scale and rural vendors would be threatened. Sadaf \& Shyama (2010) opined that the whole concept of shopping supply-side efficiencies in terms of reaching retail productivity targets need to think about demand-side efficiencies in terms of satisfaction of customers' needs in order to optimize business performance.

$>$ It is important to identify efficiency levels of the various dimensions of satisfaction of customers' needs that directly link to measures of specific firm outputs that firms intend to maximize in addition to supply side efficiencies (Blose et al, 2005).

\section{Research Design}

The Indian retail industry saw high development in the course of the most recent decade with a recognizable move towards present day retailing. Current exchange incorporates general stores, hypermarkets and other sorted out retail outlets while a lot littler supermarkets are grouped under conventional channels. The invasion of corporate elements into basic need retailing has been highly bantered in the recent past in perspective on its geniuses and cons. The disputes of the promoters and contenders of present day staple retailing As it has been over 10 years since current retailing began to make advances into the Indian market, now is the ideal opportunity for taking up a review at skillet India level to check the ground substances as against the prior projections or observations towards the cutting edge versus customary basic need retailing. So the creators thought it appropriate to check out the situation to recognize key patterns, which thusly would give basic experiences to the academician's, analysts and arrangement producers. has adjusted with a development from the disorderly to the sorted out segment and dynamic customer purchasing conduct is introducing an insurgency in shopping in India. Mandhachitara and Santimauro (2011) test ined how the customary type of grocery retailing in Bangkok, Thailand making the most of its authoritative insurance from the cutting edge retail designs, which was in the long run pulled back because of weight from the US' trade representative's and the World Trade Association in 1990. It was discovered that half of the conventional outlets were shut down because of enormous presentation of hypermarket's and comfort stores by 2010 while the remainder of the stores made due by intra-development. Richa (2011) found that Most of the supermarkets turnover had diminished because of the opening of present day markets in the region of kirana (mother and pop) stores in Kotacity and the effect was progressively unfriendly where the distance was shorter. Goswami (2009) explored writing on basic need retail- ingand found blended proof on the effect of present day basic supply retailers over the customary units. The creator's key discoveries have been talked about underneath: Although customary retail right now establishes more than 95 percent of the absolute deals in the nation littler kiranas(small mother and pop stores) that are unfit to contend with new age retailers regarding variety and scale have started losing volume in a few pieces of the nation (Vijayraghavan and Ramsurya, 2007). Globally while a few examinations propose that enormous scale retailers like Wal-Mart are in charge of wide-spread closings of mother and pop stores (Wal-Mart Watch, 2005; Basker, 2005) and question whether cost to networks as far as work removals and higher neediness balances against advantages of lower costs and more noteworthy comfort (Goetz and Swaminathan,2006) different investigations recommend that the procedure of innovative pulverization released by Wal-Mart has had no statistically critical long-run sway on the general size and productivity of the independent venture area in the United States (Sobel and Dean, 2006). In India present day exchange or sorted out retailing as of now represent 30 to 40 percent of staple deals in the main 6-7 urban communities of the nation (Kakkar, 2008). As pointed out by Sanghavi (2007) so far retailers who concentrated on creating.

\section{Development in Grocery Retailing}

Basic supply and sustenance retailing in present day group has achieved a promising size which is bound grow manifold in the coming years. The sustenance business is a critical piece of the Indian economy with contribution of around 30 percent of the shopper wallet (Earnest and Young, 2009). Table $1(\mathrm{~A})$ demonstrates the amazing development of basic need retailing in India amid 2008-2013 as far as esteem (69\%), though the rates of development in number of outlets and retail space remained at $3.1 \%$ and $4.8 \%$ separately. The figure from 2013 to 2018 appeared Table 1(B) shows that the division would reach to its potential and barely any real development is anticipated as for deals esteem and number of outlets. Anyway offer ing space is required to increment by $9.8 \%$ which can somewhat be credited to the cutting edge retailers' tendency to give better quality shopping knowledge to the customers and the passage of new players in to the division.

\section{Current versus Traditional Grocery}

Retailing-Competitive Position in Table 2(A) demonstrates the development in basic need deals during the survey time frame from 2008-2013 crosswise over modernvis a vis customary arrangements which remained at $76.2 \%$ and $68 \%$ individually, where the last isn't much falling behind the previous. Inside current organization, it is the hypermarket classification that had posted impressive development of $186 \%$ pursued by about $53 \%$ ascent in offers of markets amid the examination time frame. It might be ascribed to the rising purchaser inclination towards healthy shopping background which can well be encouraged by hypermarkets. The hypermarket is considered as an impetus and an image of retail change in Malaysia (HP Holsi, 2009). The projections for 2013-2018 in Table 2(B) recommend a negative assessment to the conventional retailers as the incentive in conjecture period marginally descends, though the cutting edge food merchants expected to accumulate about 1.75 occasions more income contrasted with the survey time frame. The expert rejected decrease in income to the autonomous grocers could be a reason for worry since a 
considerable lot of them are exceptionally defenseless. Around 95 percent of conventional grocery outlets involve less than 500 SFT space with an advantage estimation of not as much as Rs. 26600-suggesting a low capital base giving vocation to more than 40 million of whom about50 percent are under matriculates (V Sridhar, 2007). The move in purchasing behaviors of urban shoppers is to a great extent driven by their developing tendency to purchase staple under a similar rooftop in a sterile and clean condition. Further more, wide scope of items and brands, multiple installment alternatives, for example, charge or MasterCard, nourishment coupons and such essentially contributed to the development of present day basic supply retailers. On the off chance that the rising an incentive in clearance of basic supply implies the potential of the division, the development in number of outlets over the market demonstrate the dimension of reentrance

\section{Triumph of Traditional Grocery Retailers in India}

Customary food merchants remain an overwhelming power of retailing in India since $60 \%$ to $65 \%$ of the Indian populace live in provincial areas that approach just to conventional retail channels for their family unit shopping needs. Despite the fact that cutting edge basic supply retail outlets are accessible in the second-level and third-level urban areas of India, consumers keep on inclining toward conventional basic supply outlets because of the longstanding connections. Aside from that, informal acknowledge facility, quicker preparing as there is no compelling reason to remain in long lines for charging, home conveyance without an excessive number of conditions appended are a portion of the components making purchasing basic supply from customary retailers increasingly wonderful for the clients. Conventional basic supply retailers remained the biggest basic need retailers direct in India in 2013 (Table 2(A)) as far as deals containing $98 \%$ of all out staple retailers' esteem deals. This was principally because of the strength of autonomous little merchants a channel which includes for the most part mother and pop stores. By the by, development in customary basic supply retailers backed off in 2013 because of the developing fame of hypermarkets and stores in metropolitan regions of India. Anyway this log jam was insignificant and plainly most of customary grocery retailers working in India are very much aware of the way that the channel is probably going to stay very important for quite a long time to come. Euro monitor International (2015) indicates family unit spending design on staple among present day and conventional arrangements from 2000 to 2015. It demonstrates a quantum hop in the general family unit's spending on basic supply (69.5\%) anyway the running rate of development saw in spending crosswise over present day position (13.19 occasions) can to a great extent be ascribed to the low base an incentive at the outset Year.

\section{Renaissance of Modern Grocery Retailing in India}

As India is getting progressively coordinated with the world economy, change of retail division particularly in urban territories is ending up especially evident. This was basically because of the gigantic development of the cutting edge retailers' outlets the nation over towards the finish of the survey time frame. Anyway the spread of hyper-markets is especially detectable in huge urban areas with customers in littler urban areas having a tendency to lean toward mother and pop stores for fast buys of little things, despite the fact considerable contribute ment for extension and modernization. The proposition of current focal government that hypermarkets are gradually entering these urban areas too. India's home-developed general stores represent just $2 \%$ of nourishment and basic supply deals and are attempting to make a benefit. Incomes have not kept pace with rising rents.

\section{Basic supply Retailing in India-Future Outlook}

Design and nourishment will overwhelm future retailing. The US $\$ 7$ billion Indian nourishment industry, which frames around 45 percent of the whole FMCG deals, is developing at $10 \%$, guaranteeing a steady industry which can impressively impact utilization example of society and liable to change the pieces of the pie of the various sorts of sell-ers (Sreejit D. Jagathy Raj VP, 2007).The steady move towards current organization is set to reclassify the basic need retailing business in India over the conjecture period, as it is required to give Indian buyers the much touted total shopping background under one rooftop. Debajani and Hari (2008) recommend that cutting edge retail goliaths should exploit changing retail purchasing behaviors and impact the Indian customer (consumption situated progressively more youthful populace) and the development of Indian retail industry from excitement and comfort to healthy shopping knowledge and effectiveness. As the way of life of India's urban populace is becoming progressively quick paced, the utilization of the web for shopping is ending up increasingly mainstream prompting the likelihood that urban Indian purchasers may likewise begin exploring different avenues regarding on the web basic supply retailing so as to make the whole family unit shopping process quicker and progressively effective. Anyway the same number of consumers in India particularly those living in rural and rustic regions keep on wanting to search for crisp sustenance and vegetables once a day the solid development expected in web retailing won't really be exchanged to basic supply retailers. The web retailing of basic need items stayed unimportant in India toward the finish of the audit time frame. Online food merchants, for example, bigbasket.com and naturesbasket.com are coming well known among India's urban purchasers in spite of the fact that they have an exceptionally little customer base. Development here is confined because of low dimension of web entrance and absence of mindfulness and trust that significant piece of consumers have in these sites as they are more focused at specialty sections. As "Advanced India" battle gets force and accessibility of fast between net availability is particularly in the offing, the real change in online basic supply retailing isn't rules

\section{Conclusion}

The investigation of information and audit of important writing recommends that the development and examples of the dispersion items made accessible that hold the key for a picking up and holding the client base in the exceptionally competitive scene. The brilliant figure for the cutting edge retailers should rule out smugness since the challenge just gets progressively serious and the clients will in general be more requesting and perceiving than any other time in recent memory. As the apparently full grown customary basic need retailing isn't required to develop altogether, the little retailers ought to figure out how to keep pace with the changing occasions and update themselves as far as innovation appropriation client administration and so forth. There is a need to patch up and rebuild the conventional method for acquisition and retailing of staple which calls for to give access to formal credit to little and negligible build up ments ought to be adequately actualized to support and 
reinforce the little retailers. At the large scale level the market needs both a developing and dynamic current retail position and a develop customary arrangement to take into account the developing needs of the differing fragments.

\section{References}

[1] Basker, E. (2005). Job Creation or Destruction? LaborMarket Effects if Wal-Mart Expansion. The Review of Economics and Statistics. 87, 174-183.

[2] Chain Management Lotus Pang SuanKaeo Hotel Chiang Mai Thailand December.

[3] Richa, J. (2011). Organized Retailing and its Effect on Grocery Stores with Special Reference to Kota City.

[4] Journal of Marketing \& Communication. 6(3), 21-29. Sadaf, S., \& Shyama, K. (2010). Delighting the Customers' Senses - Key to Store Differentiation. Indian Journal of Marketing Number, 40(6). Sanghvi, N. (2007). I have seen the future and it works. The Economic Times, Kolkata Edition, pp. 4.

[5] Shaik, S. B. (2009). The Economic Impact of Department Stores on Small Vendors in Kurnool District Andhra Pradesh. Indian Journal of Marketing, 39.

[6] Shankar, G., \& Priya, S. (2009). Corporate Retail: Dangerous Implications for India's Economy. Economic and Political Weekly, 44.

[7] Sobel, R. S., \& Dean, A. M. (2006). Has Wal-Mart Buried Mom and Pop?: The Impact of Wal-Mart on Self

[8] Employment and Small Establishments in the United States. Retrieved from
www.be.wvu.edu/divecon/econ/sobel/WalMart/Walm art.pdf last accessed on 23.2.07.

[9] Som, A. J. (2012). An Empirical Study on Factors Influencing Store Image, Satisfaction and Loyalty in Department Stores. Graphic Era University, Dehradun Unpublished manuscript. Retrieved on 20th May 2015 from http:// shodhganga.inflibnet.ac.in// handle/10603/5132.

[10] Sreejit, D. \& Jagathy, R. V. P. (2007). Organized Retail Market Boom and the Indian Society. International Marketing Conference on Marketing \& Society, IIMK 8,1 .

[11] Sridhar, V. (2007). Retail Invasion Front Line, 24(13), 13. The Economist. (2014). Modern food retailing has struggled to win customers from India's old- fashioned merchants. $\quad$ Retrieved from http://www.economist.com/news/ business/21625799-modern-food-retailing-has-struggled-win-customers-indias-old-fashioned-merchantslong on 20th May 2015.

[12] Vijay, K., et al. (2008). Organised Food Retailing: A Blessing or a Curse?. Economic and Political Weekly, 43.

[13]/Vijaya, D. P. V. (2007). The spread of Organized Retailing in India-with a special Reference to Vijayawada City. Indian Journal of Marketing. 37, 3-9. Economics and Statistics. 87, 174-183. 